\title{
Intercultural Communication Competence of BIPA Students in Indonesia: A Perspective
}

\author{
Mira Nuryanti ${ }^{1}$, Elin Rosmaya ${ }^{2}$, Nunung Supratmi ${ }^{3}$ \\ ${ }^{1,2}$ Universitas Swadaya Gunung Jati, Indonesia, \\ ${ }^{3}$ Universitas Terbuka, Indonesia,

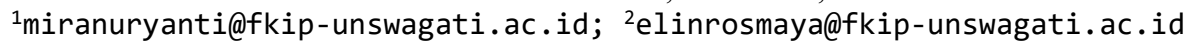 \\ 3nunung@ecampus.ut.ac.id
}

\begin{abstract}
Intercultural communication competencies are needed by BIPA students to be able to interact effectively with educators and other students. The research method used is descriptive. This is in accordance with the research objectives, namely to describe the individual perspective of BIPA teachers regarding intercultural communication of BIPA students who are studying in Indonesia based on their experiences of interacting and communicating with BIPA students. In terms of knowledge, BIPA learners have insight into Indonesian culture and other countries' cultures quite well. In terms of attitude, BIPA students are classified into two categories, racial and open. One racial attitude is to reject the culture of Indonesia or other countries so that they withdraw from the environment and avoid socialization. This attitude is individual, not as a country stereotype. BIPA students, in terms of skills, are divided into two groups. The first group tries to learn about other cultures and introduce their culture to other students. The second group covers themselves and always provides a view of their culture so they always feel that their culture is superior to other cultures.
\end{abstract}

Keywords: BIPA learners, intercultural communication competence, knowledge, attitudes, skills

\section{PENDAHULUAN}

Dewasa ini, budaya asing menjadi bagian penting bagi sebuah bangsa karena keterbukaan jaringan komunikasi. Fenomena tersebut memungkinkan manusia dari belahan dunia lain saling mengenal dan berhubungan intens serta erat [1]-[3]. Salah satu keberhasilan komunikasi ditentukan oleh kemampuan menghadapi masalah-masalah budaya [2], [4]. Cara berpikir, berperilaku, berinteraksi, dan berkomunikasi dengan orang lain yang berbeda budaya dipengaruhi oleh konstruk budaya seseorang [5]. Dengan demikian, interaksi komunikasi antarbudaya memunculkan beragam identitas sosial dan budaya yang akan memengaruhi model komunikasi antarbudaya yang khas.

Salah satu kunci utama keberhasilan dan kesuksesan dalam menjalin sebuah hubungan ditentukan oleh kemahiran berkomunikasi [6]. Komunikator harus menguasai bahasa dan budaya komunikannya agar komunikasi dapat berjalan lancar [7]. Komunikasi itu dapat terjadi antara orang-orang berbeda bangsa (international), antaretnik (interethnical), kelompok ras 
(interracial), dan komunitas bahasa (intercommunical) sebagai proses pertukaran pikiran dan makna yang berbentuk simbol-simbol [8]. Dalam komunikasi antarbudaya, suatu pesan disandi dalam suatu budaya tertentu dan harus disandi pula secara antarbudaya dengan budaya lainnya [2]. Dengan demikian, masalah-masalah penyandian pesan akan muncul dalam komunikasi antarbudaya. Untuk mengatasi masalah-masalah penyandian tersebut, komunikasi antarbudaya berperan dalam mempelajari bagaimana budaya berpengaruh terhadap aktivitas komunikasi: apa makna pesan verbal dan nonverbal menurut budaya-budaya komunikator dan komunikan, apa saja yang layak dikomunikasikan, bagaimana strategi mengomunikasikannya (verbal dan nonverbal), dan kapan mengomunikasikannya [9].

Komunikasi dan budaya mempunyai hubungan timbal balik, seperti dua sisi mata uang. Budaya menjadi bagian dari perilaku komunikasi dan pada gilirannya komunikasi pun turut menentukan memelihara, mengembangkan, dan mewariskan budaya [3], [10]. Dengan demikian, komunikasi adalah budaya dan budaya adalah komunikasi. Pada satu sisi, komunikasi merupakan suatu mekanisme untuk menyosialisasikan norma-norma budaya masyarakat, baik secara horizontal dari suatu masyarakat kepada masyarakat lainnya, ataupun secara vertikal dari suatu generasi ke generasi berikutnya [8]. Pendapat Byram dan Samovar mengukuhkan hubungan erat antara budaya dan komunikasi dalam interaksi komunikasi.

Komunikasi antarbudaya dalam kehidupan berhubungan dengan bidang ekonomi, sosial, globalisasi budaya, migrasi antarnegara, dan studi ke luar negeri [3]. Penelitian berikut ini mendeskripsikan kesulitan komunikasi antarbudaya mahasiswa Jepang bernama Aya yang sedang berkuliah di Australia [11]. Fenomena di atas menegaskan bahwa pemahaman antarbudaya urgen untuk dikuasai mahasiswa yang sedang berkuliah di luar negeri agar tidak terjadi frustasi dan kegagalan [4]. Dengan demikian, dalam dimensi pendidikan, kompetensi komunikasi antarbudaya sangat penting bagi penutur jati bahasa Indonesia dan mahasiswa asing yang sedang intens berinteraksi dalam budaya akademik yang kompleks.

Penelitian kompetensi komunikasi antarbudaya (intercultural communication competence/ICC) selama 25 tahun direfleksikan dalam sebuah artikel dengan sejumlah temuan berikut ini [12]. Penelitian kompetensi komunikasi antarbudaya berhasil mengidentifikasi keterampilan-keterampilan dan pengetahuan siap agar seseorang memiliki kecakapan komunikasi antarbudaya atau [4]. Namun, keberhasilan tersebut memunculkan titik kelemahan, yakni instrumen penelitian yang dikembangkan ternyata tidak dapat memprediksi keberhasilan pencapaian kompetensi komunikasi antarbudaya pada budaya lain. Dengan demikian, hasil penelitian kompetensi komunikasi antarbudaya tidak dapat digeneralisasi untuk semua konteks budaya. Selain itu, belum ada penelitian tentang kompetensi komunikasi antarbudaya untuk mahasiswa BIPA berlatar budaya Indonesia.

Kompetensi dalam konteks 'Kompetensi Komunikasi Antarbudaya' bermakna sebagai penilaian sosial, yakni kesan, simpulan, dan evaluasi interpersonal [7]. Singkatnya, kompetensi komunikasi antarbudaya bukanlah sesuatu yang dilakukan seseorang melainkan sesuatu yang dirasakan seseorang. Pemelajar BIPA harus memiliki kompetensi berkomunikasi antarbudaya karena bahasa sebagai pengembang kompetensi komunikasi antarbudaya [13].

Komponen kompetensi komunikasi antarbudaya adalah (1) sikap, (2) pengetahuan, dan (3) keterampilan [14]. Ketiga komponen tersebut akan dipaparkan berikut ini [14]. Sikap adalah keingintahuan dan keterbukaan, kesiapan untuk menangguhkan ketidakpercayaan tentang budaya lain, dan kepercayaan tentang budaya seseorang. Pengetahuan bermakna wawasan tentang kelompok sosial, produk, praktik berkomunikasi di negara lawan bicara dan tentang proses umum interaksi sosial dengan individu. Keterampilan merujuk pada Kemampuan untuk menafsirkan dokumen atau peristiwa dari budaya lain, untuk menjelaskannya dan mengaitkannya kepada dokumen milik sendiri. 


\section{METODE PENELITIAN}

Metode penelitian yang digunakan adalah deskriptif. Hal ini sesuai dengan tujuan penelitian, yakni untuk mendeskripsikan perspektif individual guru BIPA mengenai komunikasi antarbudaya mahasiswa BIPA yang sedang belajar di Indonesia berdasarkan pengalaman mereka berinteraksi dan berkomunikasi dengan pemelajar BIPA. Data dalam penelitian ini berupa data kualitatif yang berwujud verbal lisan, yakni jawaban pertanyaan yang diperoleh pada saat proses wawancara mendalam. Wawancara mendalam (indepth interview) dilakukan pada seluruh partisipan untuk mendapatkan persepsi tentang komunikasi antarbudaya pemelajar BIPA. Persepsi atas kemampuan komunikasi antarbudaya bersifat personal, yakni hasil pengalaman masing-masing individu dalam berinteraksi [7]. Mereka berpengalaman dalam berinteraksi dan berkomunikasi dengan mahasiswa BIPA, baik di dalam kelas maupun di luar kelas. Berdasarkan pertimbangan tersebut, Sumber data adalah dua orang guru BIPA yang telah mengajar lebih dari tiga tahun dan pernah mengajar mahasiswa BIPA dengan latar belakang dari beberapa negara.

\section{HASIL DAN PEMBAHASAN}

Subjek penelitian pernah mendengar dan mengetahui tentang kompetensi komunikasi antarbudaya karena sebelumnya mereka pernah mengikuti pembekalan pengetahuan kompetensi komunikasi antarbudaya sebelum menjadi guru BIPA. Namun, pengalaman berkomunikasi (aspek sikap dan keterampilan) dengan penutur asing hanya diperoleh ketika mereka mengajar BIPA. Ketika mereka berhadapan langsung dengan pemelajar BIPA, aspek sikap dan keterampilan lebih dominan diaplikasikan. Di lapangan, mereka mempelajari budaya pemelajar dari berbagai negara secara autodidak, yakni mencari informasi budaya para pemelajar dari artikel, buku, guru BIP yang lain, proses pembelajaran di kelas, dan bertanya langsung kepada pemelajar asing . Pemelajar BIPA pun sama. Mereka memiliki pengetahuan komunikasi antarbudaya berdasarkan pembekalan di negaranya sebelum pergi ke Indonesia. Pemelajar BIPA tidak memiliki pengalaman berinteraksi dengan pemelajar lain dari berbagai negara dengan latar budaya Indonesia. Pemelajar BIPA tumbuh dari budaya dan agama yang berbeda dengan penduduk setempat, tetapi kepribadian mereka tetap berjati diri budaya 'bawaannya' dan mau belajar serta beradaptasi pada budaya baru. Oleh karena itu, budaya akan membentuk kepribadian seseorang [8]. Dengan demikian, aspek sikap dan keterampilan diperoleh ketika mereka berpraktik langsung di kelas atau di luar kelas.

Beberapa pemelajar menunjukkan kompetensi komunikasi antarbudaya berdasarkan pandangan mereka terhadap budayanya. Pemelajar dari Eropa atau Amerika cenderung melakukan penolakan terhadap penggunaan kata sapaan untuk orang tua. Mereka merasa hal tersebut tidak adil karena perlakuan kepada orang tua harus menggunakan kata sapaan, tetapi sebaliknya, sapaan kepada yang muda cukup menyebutkan nama misalnya. Sementara itu, di negaranya, kata sapaan tidak mengenal klasifikasi usia. Mereka boleh menyebutkan nama ketika menyapa. Sebagian pemelajar menyampaikan protes kepada guru BIPA, sebagian lagi langsung menyatakan penolakan sehingga mereka menghindari interaksi dengan teman-teman yang lain ataupun dengan masyarakat sekitar mereka. Pemelajar BIPA terkadang memaksakan kehendak kepada pemelajar lain karena menganggap budayanya yang terbaik. Hal terebut ditunjukkan dengan sikap. Kadang seperti tidak terlihat, tetapi ditampakkan dalam perilaku berkomunikasi. Selain itu, mereka bersikap rasis sehingga menunjukkan penolakan kepada pemelajar lain dengan menarik diri dari lingkungan kelas (individual). Ketika kita berhadapan dengan budaya lain, janganlah menggeneralisasi bahwa budaya kitalah yang terbaik, 
menganggap budaya lain aneh, dan akhirnya kita tidak dapat menerima budaya tersebut [15]. Dengan demikian, kompetensi komunikasi budaya adalah kemampuan memahami dan mengapresiasi budaya lain sekaligus memperkenalkan budaya sendiri dengan santun dan tanpa paksaan.

Urgensi penguasaan komunikasi antarbudaya bagi penutur asing yang sedang belajar di negara lain, di antaranya sebagai berikut [14]. Pertama, Lembaga pendidikan memiliki kewajiban untuk membentuk self efficacy (keefektifan diri) dan konsep diri meskipun itu untuk sojourner (pendatang) agar mereka loyal terhadap kelompok baru dan membentuk identitas kelompok baru. Kedua, para sojourner harus diterima sebagai pendatang untuk grup sosial tertentu. Ketiga, komunikasi antarbudaya lebih dari sekadar pertukaran informasi dan pengiriman pesan, yakni membangun dan memelihara hubungan antarpendatang serta antara pendatang dengan tuan rumah. Keempat, pertukaran informasi bergantung pada pemahaman terhadap apa yang dikatakan atau ditulis kemudian dirasakan dan ditafsirkan dalam konteks budaya lain. Pendapat Byram menegaskan urgensi kompetensi komunikasi antarbudaya untuk keefektifan sebuah komunikasi (self efficacy of communication) yang berlatar perbedaan budaya bagi penutur asing yang sedang berkuliah ataupun belajar di negara lain.

Mahasiswa BIPA yang berlatar belakang jurusan bahasa, terutama Bahasa Indonesia, lebih bersikap sopan dan apresiatif terhadap budaya Indonesia dan budaya pemelajar lainnya. Sementara itu, dari jurusan lain cenderung bersikap arogan dan individual. Pemelajar BIPA yang berasal dari negara Eropa dan Australia, pada umumnya sering bersikap rasial, meskipun tidak dapat digeneralisasi. Mereka berpersepsi bahwa peradaban dan penampilan fisik lebih baik daripada negara Asia dan Afrika. Dalam konteks pengajaran bahasa asing [10] [16], sebuah model kompetensi komunikasi antarbudaya tidak bisa digeneralisasikan untuk budaya lain.

\section{SIMPULAN}

Pemelajar BIPA dapat menampilkan tiga komponen kompetensi komunikasi antarbudaya, yakni pengetahuan, sikap, dan keterampilan. Pada umumnya, mereka memiliki wawasan kebudayaan yang baik, tetapi pada aspek sikap dan keterampilan, mereka memperoleh sejumlah kendala. Pada saat mereka datang ke Indonesia dan berinteraksi dengan pemelajar serta guru, pemelajar BIPA berhadapan dengan budaya baru dan beragam. Hal tersebut membutuhkan kompetemso komunikasi antarbudaya yang baik. Dengan demikian, diperlukan penilaian kompetensi komunikasi antarbudaya sebelum mereka bersosialisasi dalam kanekaragaman budaya. Hasil penilaian akan menentukan pelatihan berupa pembekalan budaya yang bersifat komprehensif, yakni dari aspek pengetahuan, sikap, dan keterampilan. Urgensi kompetensi komunikasi antarbudaya menjadi pijakan awal dalam memetakan kesiapan mental mahasiswa untuk belajar dan berinteraksi di kelas maupun dengan masyarakat sekitar.

\section{REFERENCES}

[1] D. Mulyana and A. Zubair, "Intercultural Communication Competence Developed by Chinese in Communicating With Malays in Bangka Island, Indonesia," Sino-US English Teach., vol. 12, no. 4, pp. 299-309, 2015.

[2] M. Shoelhi, Komunikasi Lintas Budaya dalam Dinamika Internasional. Bandung: Simbiosa Rekatama Media, 2015.

[3] I. Piller, Intercultural Communication: A Critical Communication. Edinburgh: 
Edinburgh University Press, 2011.

[4] D. Mulyana, Komunikasi Lintas Budaya. Bandung: Remaja Rosdakarya, 2015.

[5] A. Ridwan, Komunikasi Antarbudaya: Mengubah Persepsi dan Sikap dalam Meningkatkan Kreativitas Manusia. Bandung: Pustaka Setia, 2016.

[6] N. Syam, Model-model Komunikasi:Perspektif Pohon Komunikasi. Bandung: Simbiosa Rekatama Media, 2013.

[7] J. Koester and M. W. Lustig, "Intercultural communication competence: Theory, measurement, and application," Int. J. Intercult. Relations, vol. 48, pp. 20-21, 2015.

[8] L. A. Samovar, R. E. Porter, E. R. Mcdaniel, and C. S. Roy, Communication Between CULTURES, Eight. Boston: Wadsworth Publishing Company, 2013.

[9] D. Mulyana, Komunikasi Efektif-Suatu Pendekatan Lintas Budaya. Bandung: Remaja Rosdakarya, 2008.

[10] M. Byram, "Assessing Intercultural Competence in Language Teaching," Sprogforum, vol. 18 , no. 6 , pp. $8-13,2000$.

[11] I. Nakane, Silence in Intercultural Communications. Amsterdam: Jhon Benjamins, 2007.

[12] D. J. Kealey, "Some strengths and weaknesses of 25 years of Research on Intercultural Communication Competence: Personal Reflections," Int. J. Intercult. Relations, vol. 48, pp. 14-16, 2015.

[13] M. Ryshina-Pankova, "Discourse moves and intercultural communicative competence in telecollaborative chats," Lang. Learn. Technol., vol. 22, no. 1, pp. 218-239, 2018.

[14] M. Byram, Teaching and assessing intercultural communicative competence. Multilingual Matters, 1997.

[15] R. Chi and D. Suthers, "Assessing intercultural communication competence as a relational construct using social network analysis," Int. J. Intercult. Relations, vol. 48, pp. 108-119, 2015.

[16] K. Saddhono, "Integrating culture in Indonesian language learning for foreign speakers at Indonesian universities," J. Lang. Lit., vol. 6, no. 2, 2015. 